Windle, J. (2012). 'The Suppression of Illicit Opium Production in Viet Nam: An Introductory

Narrative'. Crime, Law and Social Change, 57(4), pp. 425-439. Pre-print copy.

\title{
The suppression of illicit opium production in Viet Nam: an introductory narrative
}

James Windle, School of Law, University of East London, J.Windle@uel.ac.uk

\begin{abstract}
Between 1990 and 2001, Vietnamese opium production declined by 98\%: the causes of this reduction have received minimal academic attention. As Viet Nam is one of only a handful of states which have successfully suppressed illicit opium production, the somewhat surprising lack of scholarly attention represents an underutilised opportunity. As such, this paper represents the first step towards rectifying this gap in the knowledge base. The available evidence suggests that a number of components converged to permit suppression: (1) The state possessed authority over the majority of its territory; (2) The state placed opium farmers under extensive surveillance; (3) The state possessed leverage (rural development and law enforcement) in negotiations for 'voluntary' eradication; (4) The elite perceived suppression as in their best interest. Additionally, while the state pledged support to develop alternative livelihoods, few farmers received state assistance. This would suggest that disentives, rather than the establishment of alternative incomes, were the primary motivation for the cessation of opium production. While Viet Nam was successful in suppressing illicit opium production, the negative impact of the intervention on (ex)-opium farmers and their communities demonstrate the limitation of the Vietnamese approach.
\end{abstract}

\section{Introduction}

Viet Nam is one of a small number of countries to administer interventions which have 'successfully' removed the illicit production of opium from their national territory. ${ }^{1}$ Between 1990 and 2001, Vietnamese opium production declined by $98 \%$ from a peak of 90 metric tonnes to two metric tonnes. It is therefore surprising that a unique opportunity to improve our understanding of the processes by which large-scale opium production can be suppressed

\footnotetext{
${ }^{1}$ Other cases include: China (under the Qing Dynasty); the People's Democratic Republic of China; Iran (under the Pahlavi Dynasty); Turkey; the Islamic Republic of Iran; Thailand; Pakistan; and the Lao People's Democratic Republic.
} 
Windle, J. (2012). 'The Suppression of Illicit Opium Production in Viet Nam: An Introductory Narrative'. Crime, Law and Social Change, 57(4), pp. 425-439. Pre-print copy.

has received minimal scholarly attention. This paper represents a first step towards rectifying this gap in the knowledge base.

The focus of the paper is not, however, limited to the quantitative reduction of opium production. From an international legal perspective, any definition of success must (or at least should) be centred upon two sets of outcome measurements. The first, quantifies the reduction in illicit production whilst the second should measure the impact of the intervention on opium farming communities and wider local, regional or national interests [84]. As noted by the UN Commission on Narcotic Drugs:

In the case of drug laws in particular, obligations to establish offences under the international drug conventions must be fulfilled while at the same time respecting a range of rights, including the right to health, to the protection of the child, to private and family life, to non-discrimination, to the right to life, the right not to be subjected to torture or cruel, inhuman or degrading treatment or punishment, and the right not to be subjected to arbitrary arrest or detention ([21]:8).

The UN Special Rapporteur on the Right of Everyone to the Enjoyment of the Highest Attainable Standard of Physical and Mental Health goes one step further:

When the goals and approaches of the international drug control regime and international human rights regime conflict, it is clear that human rights obligations should prevail ([68]:6). ${ }^{2}$

Obligations under international human rights law are, however, often disregard during interventions against those illicitly producing, distributing and consuming drugs. It is often the basic rights of the farmers of opium and coca which are the most frequently, and often, brutally abused [5]. Therefore, any analysis of illicit production control must be paralleled by an equal investigation into the extent of adherence to international human rights norms.

The available evidence suggests that a number of components converged to permit suppression: (1) The state possessed authority over the majority of its territory; (2) The state placed opium farmers under extensive surveillance; (3) The state possessed leverage (rural

\footnotetext{
${ }^{2}$ Viet Nam has been party to the International Covenant on Civil and Political Rights since 1982 [65].
} 
Windle, J. (2012). 'The Suppression of Illicit Opium Production in Viet Nam: An Introductory Narrative'. Crime, Law and Social Change, 57(4), pp. 425-439. Pre-print copy.

development and law enforcement) in negotiations for 'voluntary' eradication; (4) The elite perceived suppression as in their best interest. In addition, while the state pledged support to develop alternative livelihoods, few farmers received state assistance. This would suggest that disentives, rather than the establishment of alternative incomes, were the primary motivation for the cessation of opium production. While Viet Nam was successful in suppressing illicit opium production, the negative impact of the intervention on (ex)-opium farmers and their communities demonstrate the limitation of the Vietnamese approach.

This case study is intended as an introductory narrative, which will provide a foundation for more in-depth investigations utilising fieldwork and Vietnamese language documents. The paper shall begin by providing the contextual background to Vietnamese illicit opium production, before describing the specifics of the intervention.

\section{Context and background}

Opium, which is believed to have been first introduced to Viet Nam from Laos between 1,600 and 1,660, was first prohibited in 1,660 [49]. Production and consumption, however, remained small until the nineteenth-century when, alongside the migration of ethnic groups from China into the northern highlands, demand and supply gradually increased [23, 24, 44]. By 1880, French explorers in Viet Nam reported opium was produced in significant quantities by the ethnic groups of the northern highlands [23]. The largest producing group were the Hmong - who had been opium farmers in China and, as such, had searched for good opium farming land [24, 42, 44]—and, producing lesser amounts, the Dao and 'Black Tai' groups [42].

The highland areas of northern Viet Nam continued to be the centre of opium production throughout the period under review. For example, the most important provinces during the 1990s were Nghe Son, Son La, Lai Chau and Lao Lai [54]. The highlands areas remained inhabited by a number of ethnic groups of which the largest producers remained the Hmong $[42,54]$. By the 1990 s roughly $75 \%$ of all opium farmers were Hmong, while the Dao, Thai and Kho Mu groups each accounted for 5\%, with the remaining $10 \%$ coming from the Tay, Nung, Kinh, Muong and Han groups [54].

When the French colonised the territories of contemporary Cambodia, Laos and Viet Nam (as the territory of Indochina) they established a state monopoly selling imported opium (the Régie générale de l'opium) [42, 43]. While the production or consumption of nonmonopoly opium was prohibited, to avoid conflict, the highland peoples of Laos and North 
Windle, J. (2012). 'The Suppression of Illicit Opium Production in Viet Nam: An Introductory Narrative'. Crime, Law and Social Change, 57(4), pp. 425-439. Pre-print copy.

Viet Nam were permitted to produce opium for their own consumption. Nevertheless, controls on highland farmers were inadequate [54] with producers declaring just a third of all produce and smuggling surplus opium to southern China [42] and the Vietnamese lowlands, where it competed with the colonial monopoly. In 1905, to prevent competition from highland opium, the colonial Government attempted to procure all North Vietnamese opium. The low price proffered by the monopoly, however, failed to garner cooperation. Thus forcing, in 1918, the monopoly to increase the set-price sufficiently to attract Laotian and Vietnamese highland farmers' compliance. While the increased monopoly price initially decreased smuggling to the lowland markets, it quickly became common practice to adulterate highland opium with imported and inferior Burmese opium: freeing better quality Vietnamese and Laotian opium for the lowland black-market. State procurement ceased in 1925 as a result [54]. While sufficient to provoke the monopoly to take action, in global terms illicit highland Indochinese production remained small throughout the 1930s [41].

Then, in response to the severing of supply lines from India, Iran and Turkey during World War Two [12], the colonial monopoly began promoting highland production by concurrently increasing highland land-taxes and monopoly prices [59]. Insufficient controls over rural highland areas, however, [26] meant that farmers who had previously grown only for local consumption enlarged their production in response to growing demand from both the regulated and black markets [12]. While Laotian and Vietnamese production increased [18], Indochinese production remained small in comparison to China, India, Iran and Turkey and primarily supplied the domestic market [46].

In 1946, at the beginning at the First Indochina War, opium consumption and production were prohibited [43]. Nevertheless, due to fear of violent opposition and a lack of state authority, highland Hmong and Dao peoples remained exempt from prohibition [18]. While the monopoly officially closed in 1950 [17], the French intelligence agencies operated an unofficial monopoly to finance covert operations. To maintain Hmong loyalty against the Viet Minh, opium was clandestinely procured from highlands farmers where it was sold throughout Indochina. The surplus was exported by allied organised crime groups to foreign black markets [43].

In North Viet Nam, the new Vietminh Government-who were ideologically opposed to opium [83] - prohibited consumption and ordered the gradual suppression of highland production. While little information is available on the extent of Vietminh involvement [54], it appears that there was some unregulated production in highland areas 
Windle, J. (2012). 'The Suppression of Illicit Opium Production in Viet Nam: An Introductory Narrative'. Crime, Law and Social Change, 57(4), pp. 425-439. Pre-print copy.

$[19,20]$ outside of Vietminh authority [17, 42]. This said, John McAlister suggests that the Vietminh facilitated opium production which they exchanged for weapons in southern China [42]. Furthermore, Laos continued to be the more significant producer [18] and in 1953 the Vietminh invaded the four largest Laotian opium producing provinces: which together accounted for $70 \%$ of Indochinese production [39]. That the occupation persisted just long enough to harvest opium $[82]^{3}$ demonstrates not only the importance of opium but may also suggest that North Viet Nam possessed insufficient opium for either profit or medicine.

\section{4-1990s}

In the late-1960s/early-1970s around 500,000 American troops were stationed in Viet Nam to support the South Vietnamese Government against the Viet Cong and North Vietnamese Government [8]. It is estimated that as many as 10 [47] to 35\% of American troops consumed heroin in Viet Nam: 19\% became clinically dependent [57]. Hence, the existence of American troops represented a major enhancement of demand for Southeast Asian opiates. The Vietnamese heroin market was supplied from opium produced in Burma, Laos and Thailand; supplemented with, at most, minimal Northern or Southern Vietnamese produced opium [37, 47]. The South Vietnamese Government, for example, claimed that illicit production had ceased in 1955 [64] after an extensive forced eradication campaign [49].

In 1971, a US Provost Marshal reported that the North Vietnamese Government had regulated some farmers to produce opium for medicinal purposes. Little was diverted from the licit production [43] as the state effectively enforcement the ban on unauthorised production in areas under their authority. This said, as the Government lacked the resources to provide isolated opium farmers with alternative incomes or modern medicines a certain amount of production for local demand was unofficially tolerated in some areas. Part of this toleration was to avoid destabilising strategically important border regions by local opium farming populations [54].

In 1975, the country was reunified as the Socialist Republic of Viet Nam. American Congress [15] and the Chinese state controlled media [7, 61, 77] soon began accusing the Vietnamese Communist Government of supporting the production and export of opium for

\footnotetext{
${ }^{3}$ A practice adopted by the Pathet Lao and Royal Lao Government during the Second Indochina War [27].
} 
Windle, J. (2012). 'The Suppression of Illicit Opium Production in Viet Nam: An Introductory Narrative'. Crime, Law and Social Change, 57(4), pp. 425-439. Pre-print copy.

non-medical/scientific purposes, to cover extensive national debts. ${ }^{4}$ While the evidence to support these claims remains limited to one (allegedly genuine) 1982 official Vietnamese Government document, alternative evidence suggests that between 1975 [10] and the early1980s the state procured highland opium for domestic and foreign pharmaceutical (i.e. licit) consumption. These accounts suggest that farmers began selling their opium on the black market only once state procurement ceased around 1985 [see 10, 54].

The extent of illicit production remains unclear. In 1986, the US Congress declared Viet Nam a 'secondary' source of illicit opium alongside Afghanistan and Laos [15]: To qualify 'secondary', Afghanistan produced 160 metric tonnes in 1984 and 450 metric tonnes in 1985, while Laos produced 32 metric tonnes in 1984 and 97 metric tonnes in 1985 [69]. The United Nations Office of Drugs and Crime (UNODC) ([70]:8) has stated that 'production was systemized, and cultivation continued to be widespread.... until the early-1990s'. As illustrated in Fig. 1, American and United Nations (UN) intelligence produced widely divergent pictures of Vietnamese production: between 1977 and 1996, Viet Nam remained unmentioned by America's primary drug control publications [25, 48]. While Viet Nam was a closed society and thus data may have been unavailable to American agencies, the reports included the equally introverted Laos in their analyses. In short, the true extent of illicit opium production is unknown. What is clear, however, is that by the 1990s production was sufficiently high to concern the Vietnamese Government.

\section{The intervention}

During the early-1990s, the Vietnamese Government attitude to narcotics began to shift to a position where prohibition was perceived as in their best interest. The Government had become concerned over increasing opiate consumption [54]: the prevalence rate of drug 'addicts' per 100,000 increased from 78 to 208 between 1994 and 2004 and, importantly, opiate consumption was no longer contained to highland ethnic groups [50]. Furthermore, the Government began to see the utility in international cooperation [49], at a time when they were seeking to promote a market economy in the highland areas [54] and improve the

\footnotetext{
4 The Second Indochina War had slowed the economy, decreased agricultural productivity and increased urban unemployment [29] so that by 1981 the country was kept afloat largely by loans from the USSR [52].
} 
Windle, J. (2012). 'The Suppression of Illicit Opium Production in Viet Nam: An Introductory Narrative'. Crime, Law and Social Change, 57(4), pp. 425-439. Pre-print copy.

countries international image. ${ }^{5}$ In response, production and consumption were prohibited under Article 61 of the 1992 Constitution. This was followed, in 1993, with Decree 06/CP which set the provisions for eradication and development-orientated drug control $[10,80]$.

Production and possession were first criminalised in a 1997 amendment to the 1985 Criminal Code [49], which established the death penalty for possession of more than $100 \mathrm{~g}$ of heroin or $5 \mathrm{~kg}$ of opium [1]. While punishments for production were purposefully left vague to allow local authorities discretion in sentencing [62], ${ }^{6}$ convention required that criminal liability only be imposed if the farmer recultivated after administrative sanctions (i.e. warnings, house arrest or a fine) had been imposed. As administrative sanction records were removed after 1 year, farmers remained free to re-cultivate the following year without the (official) threat of incarceration [49].

In 2000, the Law on Preventing and Combating Narcotic Drugs [60] was passed. The Law placed a duty on all individuals and, civil and public organisations, to notify the state of any production. Additionally, it obliged the state to "help local people effectively reorient their production systems" (Article 8) after opium poppies had been eradicated. The military were mandated with organising "activities aimed at preventing and combating narcotic drugs" (Article 11). The following sections shall discuss how the legal framework was enforced.

\footnotetext{
${ }^{5}$ In 1989, a Foreign Trade Office was created to attract investment in infrastructure. Oil and petrol exploration contracts were signed with European companies [16].

${ }^{6}$ While capital punishment has, in practice, been limited to major trafficking cases [49], theoretically, the amendment could have been interpreted as permitting the death penalty for farmers who produced, and thus possessed, excess of five kilogram of opium. While there is no evidence that such an interpretation was enforced it may be important that such a punishment could have been used as a threat.
} 
Windle, J. (2012). 'The Suppression of Illicit Opium Production in Viet Nam: An Introductory Narrative'. Crime, Law and Social Change, 57(4), pp. 425-439. Pre-print copy.

Figure 1. Illicit opium production as reported by UNODC and the US State Department (1998-2001).

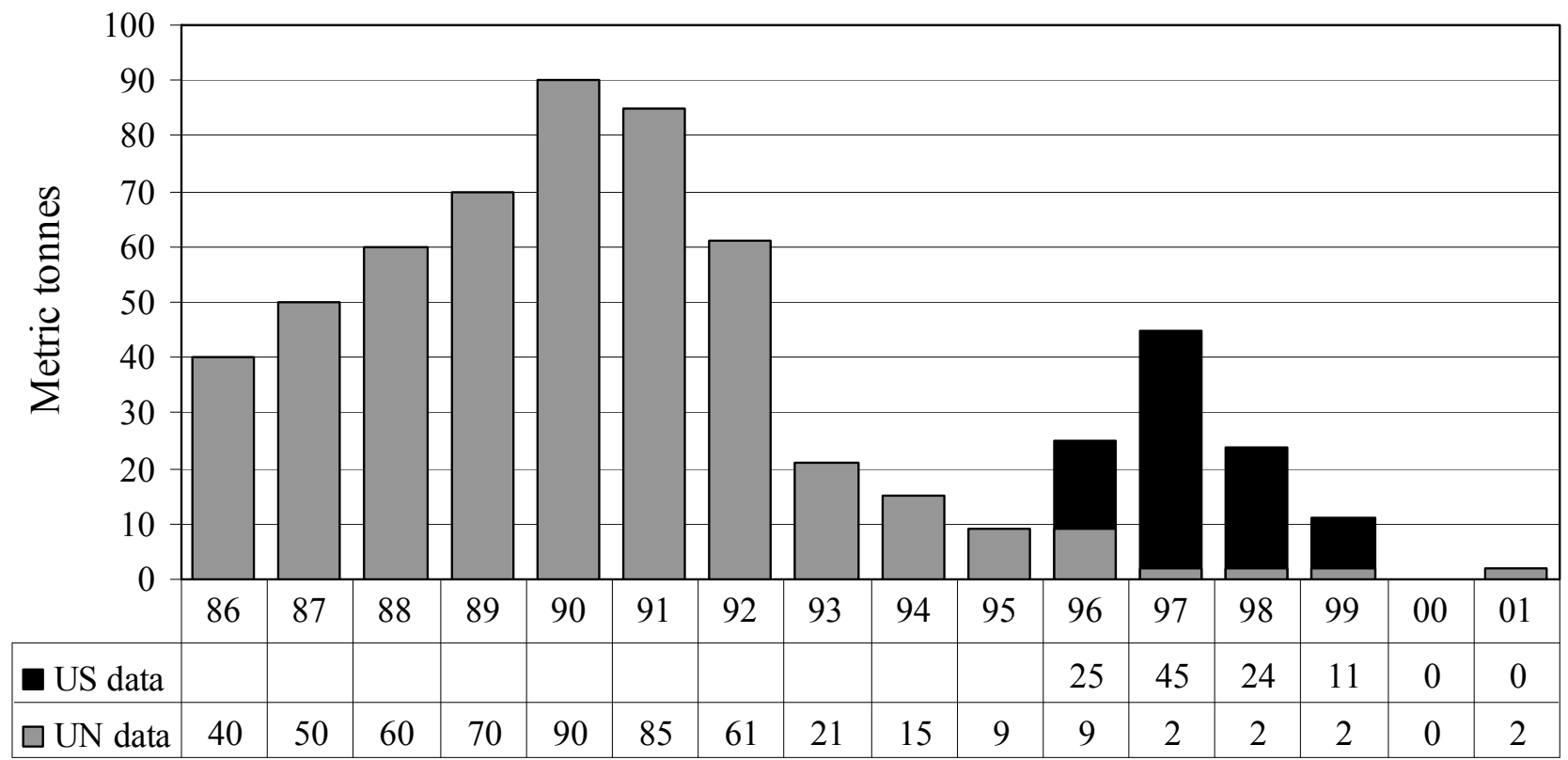

Sources: adapted from: $[69,72,75]$.

\section{Development-orientated approaches to control}

During the early-1990s, Programme 06 was developed to extend crop substitution to communes agreeing to cease producing opium; that is conditionality clauses were imposed whereby developmental assistance was conditional on the cessation of production. One discreet and foreign funded part of the Programme was the Ky Son Project (Nghe An Province) (hereafter Ky Son) [10]. ${ }^{7}$ Commencing in 1996, following best practice developed in Thailand and Pakistan [10, 67] Ky Son was centred upon community participation [56]. Commune Development Committees were formed to formulate programmes and work plans based upon the priorities identified by the communes [80]. Farmers additionally received support for the marketing of their crops. For example, commune leaders were trained in marketing and basic economic analysis so that they could offer advice on marketing and prices, liaise between merchants and farmers, distribute market information and train farmers [9].

\footnotetext{
${ }^{7}$ Prior to project initiation limited crop substitution and negotiated eradication had been administered, however, lack of operational experience had limited the previous projects effectiveness, and reduced farmers trust in the ability of the state to administer rural development. As such, many farmers initially migrated to Laos to avoid increased impoverishment [76].
} 
Windle, J. (2012). 'The Suppression of Illicit Opium Production in Viet Nam: An Introductory Narrative'. Crime, Law and Social Change, 57(4), pp. 425-439. Pre-print copy.

During the life of Ky Son: $43 \mathrm{~km}$ of road were upgraded; 10 water supply schemes were created [71]; irrigation systems were upgrade and mini-hydropower stations were constructed [76]. As road access improved lowland merchants began entering the highlands to procure crops direct from the farm-gate, [80] however, continual high-transportation costs and the scarcity of local markets limited marketing efficiency [9]. Farmers were trained in modern agricultural techniques whilst improved $[67,80]$ and new crops (i.e. coffee Arabica, tea and legumes) were promoted. To compliment the introduction of improved animal feed [56], more efficient animal feed storage techniques were developed [10]. Improved animal breeds were imported [56] and existing livestock were vaccinated against common diseases [76]. Improvements in the quality of local handicrafts were supported [80] and sold by the charity Craft Link in their outlets in Hanoi and to US distributers [9]. Three health stations and three schools were constructed while eight existing schools were equipped [71]. The project also initiated educational and health campaigns directed at women [13], and opium demand reduction programmes [80].

In 1994, Ky Son was one of Viet Nam's poorest districts and the country's largest source of opium [76]. Between 1993 and 1997, the area under cultivation with opium poppies was reduced from 2,800 ha to 98.5 ha: production ceased completely by 1999 [56]. While the project improved the quality of life and food security of many families [80], by the end of the first phase the district continued to be one of Viet Nam's poorest areas [71].

Ky Son is not, however, representative of the wider national intervention. Nationally, before 1998, rural development and/or gradually decreasing compensation were provided to communes pledging to immediately cease production [10]. For example, in Khao Khoang farmers were taught new skills, fruit trees were imported, a fishpond was built and irrigation infrastructures were improved. Nonetheless, as profits from new crops were significantly less than had previously been received from opium, many households were unable to feed themselves for parts of the year [53, see 45]. Many rural development initiations require several years before they provide sufficient income, for example, fruit trees often involve long gestation periods before yielding profitable fruit while gaining entry into new consumer markets can be a long process.

To attract developmental assistance and compensation many non-opium farmers began cultivating opium $[11,55]$. In 1998, the Vietnamese Government responded to this reverse conditionality by abandoning support targeted exclusively on opium farmers. 
Windle, J. (2012). 'The Suppression of Illicit Opium Production in Viet Nam: An Introductory Narrative'. Crime, Law and Social Change, 57(4), pp. 425-439. Pre-print copy.

Assistance was instead administered on a 'case-by-case' basis dependent on the national poverty reduction campaign, rather than on a commune's opium production [55].

Hence, after 1998, all rural development was administered under the 'Programme for Socio-Economic Development of Communes in Especially Difficult Circumstances in Mountainous and Remote Areas'. As the Programmes objective was to develop the 1,000 most underdeveloped communes, which included all major opium producing areas, opium suppression was mainstreamed into national rural development objectives. Under the Programme, each commune was provided with an annual budget of roughly US $\$ 28,500$ to manage one or two urgent projects [10]. The projects remained very top-down [30] and involved resettling some communes into new lowland villages [79]. ${ }^{8}$ The state additionally trained farmers in new agricultural techniques and promoted new or more efficient cash crops and animal breeds, handicraft industries and tourism [63].

Nonetheless, the expenditure per capita on development remained lower in opium producing areas than the national average [4, 55, 70]. Furthermore, the lack of viable economic alternatives and strict, immediate, bans reduced many households annual income $[6,45]$, forcing many farmers to sell their land and migrating higher up the mountain [22]. The redeemer for many communes was a boom in tourism, which "provided an unexpected opportunity for extra income". As the Government expanded the transport infrastructure, to accommodate the new influx of tourists' highland peoples began to sell traditional handicrafts and local produce. Tourism, in some areas, became the primary substitute for opium ([45]:91).

During the period under review, Viet Nam was "perhaps the best-performing country in Southeast Asia" due to "rapid economic growth". As a result, the percentage of the population living below the poverty line decreased from $70 \%$ in the mid-1980s to $30 / 40 \%$ in 2000. Viet Nam, however, remained a poor country and there were several instances of rural unrest at the unequal pace of urban/rural economic growth ([28]:485): the major opium producing areas in the remote highland areas lagged behind lowland and urban areas, and remained plagued by “chronic poverty" ([70]:8).

\section{Law enforcement approaches}

\footnotetext{
${ }^{8}$ A practice which has been administered and heavily criticised in Laos. Many newly settled Laotian farmers have reported decreased agricultural/livestock productivity, multiple health concerns and conflicts with local populations [4].
} 
Windle, J. (2012). 'The Suppression of Illicit Opium Production in Viet Nam: An Introductory Narrative'. Crime, Law and Social Change, 57(4), pp. 425-439. Pre-print copy.

Since 1992, the "government policy [was]... to eradicate opium poppy cultivation as soon as possible" [10] and centred upon "eradication programs, not AD [Alternative Development] interventions" ([11]:9). Large-scale 'negotiated' eradication began in 1992 [38]. As a significant state presence existed even in the most isolated areas [70], before opium poppy seeds were sown surveillance was increased [55] from already intrusive levels [2, 31] and 'prevention' campaigns were initiated by the state [55]. Prevention included a mixture of "stern threats" ([11]:12), anti-opium propaganda [81] and promises that those conforming to the ban would receive support from the state in the form of either crop substitution or compensation [10].

While arrest and prosecution were officially reserved for systematic re-cultivation [14, 54], farmers were 'administratively' punished [40]. For example, farmers could be placed under increased surveillance or ordered to reside (possible under house arrest) and work in a specified area $[31,73]$. Under the 2005 Penal Code, opium production could officially be punished with three to 6 years administrative detention [51]. Administrative punishments were a central feature of the Vietnamese penal system throughout the period under review [31, 33] and, as such, may have featured prominently before their codification as an official punishment in the 2005 Penal Code.

In opposition to the Governments claim that few farmers were punished, between 1992 and 2000 there were several reports indicating the abuse of lowland and highland peoples by the Vietnamese criminal justice system, including: police brutality, torture, forced confessions and prison conditions which threaten the health of prisoners (including the use of shackles) [31-35, 73]. Therefore, while there are no verifiable accounts of opium farmer's being abused by the state for producing opium, such a situation appears plausible. The challenge would be to gage to what extent.

Furthermore, there are accounts of the military forcing eradication [1,36] as early as 1992 [14, 40]. During the Ky Son project, eradication was undertaken so quickly and efficiently by the Border Army Force that it was "difficult for the project to.... fill the needs and demands created among the former opium growers" ([80]:132). Additionally, in several areas, opium poppies were forcefully eradicated before establishing alternative incomes [70]. Importantly, as is illustrated in Fig. 2, since 1992 in all but 2 years more than 20\% of opium poppies cultivated where eradicated.

Additionally, between 1994 and 1999, 95 people were executed and 66 received life sentences for trafficking [78]: between 1997 and 2001, 335 people were executed for 'drug 
Windle, J. (2012). 'The Suppression of Illicit Opium Production in Viet Nam: An Introductory Narrative'. Crime, Law and Social Change, 57(4), pp. 425-439. Pre-print copy.

offences' while 285 received life sentences [74]. As the execution of traffickers was conducted publically [3] the threat of execution may have had an anticipatory effect on farmers: public executions may have increased the perceived risk of opium production above that which actually existed. ${ }^{9}$

Regardless of the impact on farmers, the death penalty for drugs offences represents a contravention of international law. The UN Commission on Narcotics has stated that:

The International Covenant on Civil and Political Rights specifies that in countries which have not abolished the death penalty, the sentence of death may be imposed only for the "most serious crimes". The concept of "most serious crimes" is limited to those where it can be shown that there was an intention to kill which resulted in the loss of life. The weight of opinion indicates that drug offences (such as possession and trafficking) and those of a purely economic nature do not meet this threshold ([21]:7).

Furthermore, the UN General Assembly has stated that:

... public executions add to the already cruel, inhuman and degrading nature of the penalty and can only have a dehumanizing effect on the victim and a brutalizing effect on those who witness the execution ([67]:6).

... public executions add to the already cruel, inhuman and degrading nature of the penalty and can only have a dehumanizing effect on the victim and a brutalizing effect on those who witness the execution ([67]:6).

\footnotetext{
${ }^{9}$ Law enforcement interventions designed to increase the perception of risk, even if the actual level of risk has yet to change, are referred to in the crime prevention literature as 'anticipatory benefit' [58]. Due to the illegality under international law of public executions, it would be wrong to declare them a 'benefit': 'effect' is a more appropriate term. It must be noted that the anticipatory effect of public executions has yet to be the subject of crime prevention scholars. The influence that the public execution of traffickers had upon opium farmers is, at present, an untested hypothesis which would require verification of farmers' level of awareness. As many farmers remain isolated from modern media [54] this would depend on whether traffickers were executed in or near major production areas.
} 
Figure 2. Viet Nam: Eradication/harvest ratio (1992-2008).

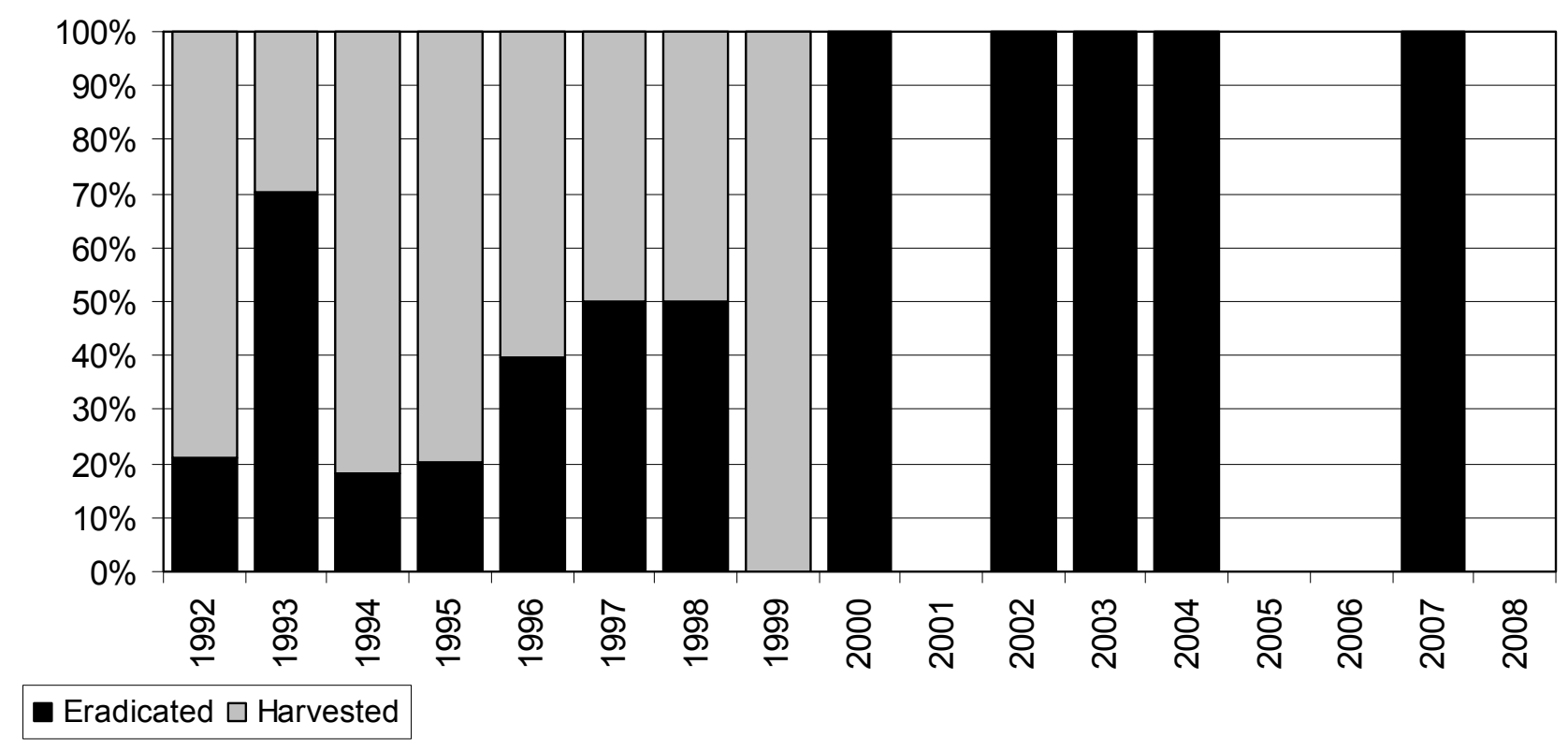

Sources: adapted from $[72,75]$. Note: missing values indicates missing data.

\section{Intervention}

The Government of Viet Nam have, since the early-1990s, remained committed to removing illicit production from the Vietnamese territory. While political will may be a prominent feature of national success (in reducing opium production) [70, 76], Ami-Jacques Rapin and colleagues [55] posit the centrality of 'negotiated' eradication, extensive surveillance and the inclusion of conditionality clauses in non-opium rural development projects.

Viet Nam had reduced production from 61 metric tonnes to 15 metric tonnes by the time that Ky Son was initiated or that drug control was mainstreamed into national rural development policies. This would suggest that rural development, be it alternative development or crop substitution, was insufficient motivation for the cessation of opium production. It appears more likely that reductions from 1993 onwards were centred upon coercive negotiations in which 'stern threats' of violence or administrative sanctions coupled with promises of rural development motivated farmers to cease production. The anticipatory effects of the public execution of traffickers may have provided additional leverage to negotiations. This said, the intervention would not have been possible without a government who perceived suppression as in their best interest, possessed authority over the majority of its national territory and had the capability to monitor farmers and administer law enforcement. 
Windle, J. (2012). 'The Suppression of Illicit Opium Production in Viet Nam: An Introductory Narrative'. Crime, Law and Social Change, 57(4), pp. 425-439. Pre-print copy.

\section{Success?}

Since 2000, Viet Nam has been classified as "other Asian countries" in UN Office of Drug Control and Crime Preventions/UNODCs annual Global Illicit Drug Trends/World Drug Report statistical tables $[69,72]$. Conversely, until 2005, the US State Department designated Viet Nam a "major drug-producing nation". The US classification was, however, based upon data collected in 2000 and disputed by UNODC [70]. Using the average of the US State Department and UNODC data, Fig. 3 shows that, with a 1-year exception (1997), from 1992 onwards Viet Nam produced less than 20 metric tonnes. If the last recorded production data is used then a $98 \%$ reduction occurred between the peak production of 1990 and 2001. Viewed from another perspective, Fig. 4 shows how during the period under review the amount of arable land cultivate with opium poppies declined from an estimated $0.285 \%$ to practically zero.

Quantifiable drug control aside, it appears that development projects had little success in alleviating poverty during the intervention period and may have worsened former opium farmers living conditions [22]. As Jean Michaud and Sarah Turner suggest, tourism became the only viable substitute for many former opium farmers [45]. Hence, the abusive nature of the intervention, in combination with its economic effect on (ex)-opium farmers, would suggest that the interventions negatively impacted (or at best, did not positively impacted) (ex)-opium farmers and their communities. Consequently, conflicting with Viet Nam's obligations under international human rights law.

Figure 3. Illicit opium production (1986-2008)

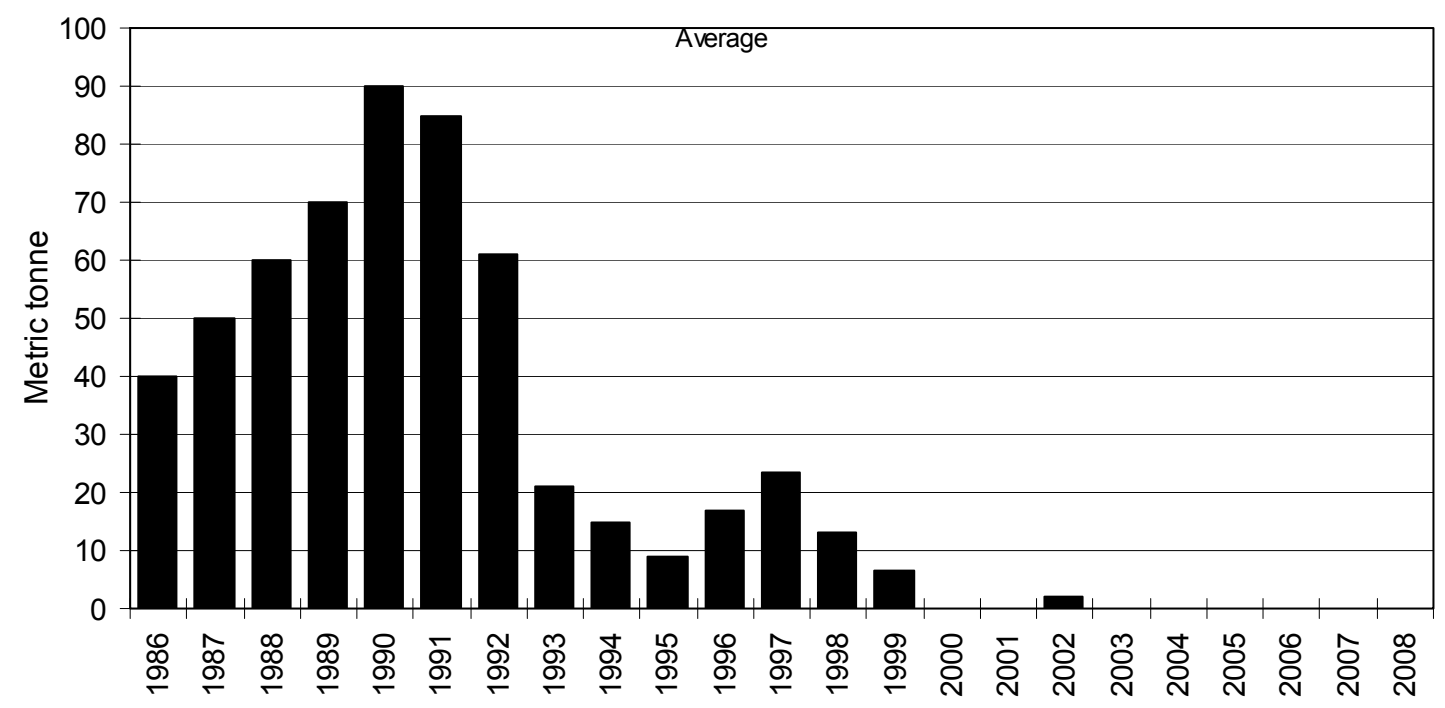


Windle, J. (2012). 'The Suppression of Illicit Opium Production in Viet Nam: An Introductory Narrative'. Crime, Law and Social Change, 57(4), pp. 425-439. Pre-print copy.

Source, adapted from Figure Two using the average score calculated from UNODC and US State Department data. Missing values indicates missing data.

Figure 4. Area under cultivation as percentage of arable land (1986-2008)

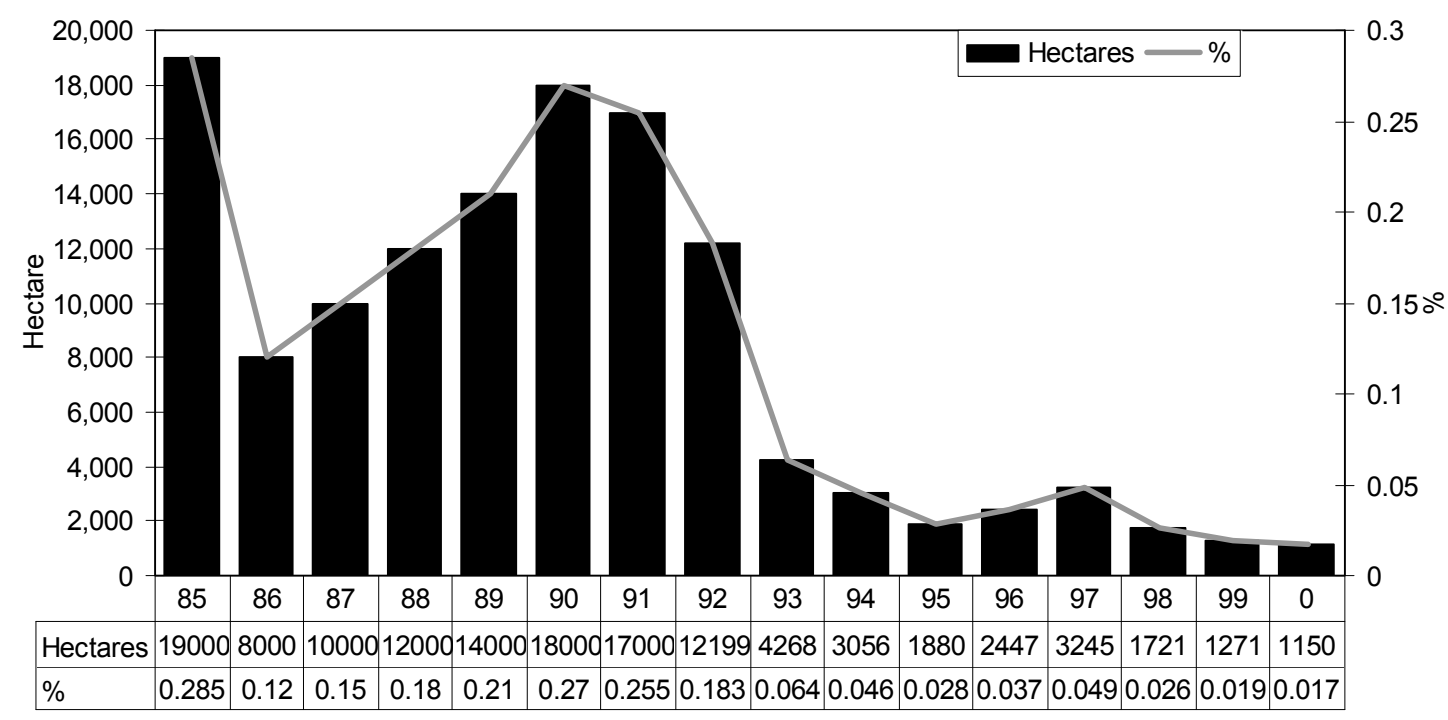

Sources: adapted from: $[69,72,75]$.

\section{Concluding remarks}

This paper has provided an introductory narrative on how Viet Nam became a major source of illicit opium and how it eventually suppressed illicit production. Some causal factors for (drug control) success have been extracted. These factors go some way to explaining the processes by which a major producer can suppress illicit opium production.

The available evidence suggests that a number of components converged to permit suppression: (1) The state possessed authority over the majority of its territory; (2) The state placed opium farmers under extensive surveillance; (3) The state possessed leverage (rural development and law enforcement) in negotiations for 'voluntary' eradication; (4) The elite perceived suppression as in their best interest. While the state pledged support to develop alternative livelihoods, few farmers received state assistance. This would suggest that disentives, rather than the establishment of alternative incomes, were the primary motivation for the cessation of opium production. While Viet Nam was successful in suppressing illicit opium production, the negative impact of the intervention on (ex)-opium farmers and their communities demonstrate the limitation of the Vietnamese approach. 
Windle, J. (2012). 'The Suppression of Illicit Opium Production in Viet Nam: An Introductory Narrative'. Crime, Law and Social Change, 57(4), pp. 425-439. Pre-print copy.

This introductory narrative has provided much detailed information, however, many gaps exist. The most important revolve around the lack of voice given to (ex)-opium farmers in the literature and the specifics of law enforcement, including surveillance and the role of social pressure. This paper, therefore, presents a foundation for more in-depth investigations into a unique and informative, yet neglected, aspect of source country drug control.

Acknowledgements: The author would like to thank the unknown advisor, Graham Farrell and Sinead Drew for their thoughtful and constructive comments on early drafts.

\section{References}

1. Associated Press. (2001). 'Vietnam reduces opium poppy fields'. Associated Press Online, 21 February 2001.

2. Avery, D. R. (1993). Vietnam in 1992: win some; lose some. Asian Survey, 33(1), 67-74.

3. Amnesty International. (2003). Socialist republic of Vietnam: the death penalty-inhumane and ineffective. Available at www.amnesty.org/en/library/info/ASA41/023/2003

4. Baird, I., \& Shoemaker, B. (2007). Unsettling experiences: internal resettlement and international aid agencies in Laos. Development and Change, 38(5), 865-888.

5. Barrett, D., Lines, R., Schleifer, R., Elliott, R., \& Bewley-Taylor, D. (2008). Recalibrating the regime: the need for a human rights-based approach to international drug policy. Oxford: Beckley Foundation.

6. Baulch, B., Chuyen, T. T. K., Haughton, D., Haughton, J. (2002). Ethnic minority development in Vietnam: a socioeconomic perspective. The World Bank Development Research Group Macroeconomics and Growth. Policy Research Working Paper 2836 7. BBC World Broadcasts. (1982). 'China accuses Vietnam of encouraging opium traffic to bolster economy'. BBC Summary of World Broadcasts. August 121982.

8. BBC. (2010). Timeline Vietnam. Available at http://news.bbc.co.uk/2/hi/asiapacific/country_profiles/1243686.stm

9. Bendiksen, L. (2002). 'Marketing - the bottleneck of opium eradication? Experiences from East Asia in marketing alternative development products'. Experiences from East Asia in marketing alternative development products. Opium farming and poverty as market failures: experiences in the Mekong region on marketing and micro-credit for alternative development. Regional Seminar on Alternative Development: Sharing Experiences and Good 
Windle, J. (2012). 'The Suppression of Illicit Opium Production in Viet Nam: An Introductory Narrative'. Crime, Law and Social Change, 57(4), pp. 425-439. Pre-print copy.

Practices on Micro-credit, Revolving Funds and Marketing. Held in Luang Prabang, Lao PDR 12-16 March. Bangkok: Thammada Press.

10. Boonwaat, L. (2001). 'An overview of alternative development and illicit crop eradication policies, strategies and actions in the region'. Alternative development: sharing good practices facing common problems. Regional seminar on alternative development for illicit crop eradication policies, strategies and actions 16-19 July 2001. Myanmar: UNDCP.

11. Brown, A., Bechstedt, H., Muthoo, R., Hernandez, T., Sibanda, B., Miranda, R., Ouchi, F., \& Spijkers, P. (2005). Thematic evaluation of UNODC alternative development initiatives. Vienna: UNODC.

12. Bulletin of Narcotics. (1949). Opium production throughout the world. Bulletin on Narcotics, 1, 6-38.

13. Chanthanom-Good, S. (2003). 'Engendering alternative development: emerging strategies for sustainable practices in Southeast Asia'. Emerging gender strategies for alternative development. Regional seminar on alternative development: information networking and sharing good practices on gender and development. Chiang Mai, 29-31 October. Bangkok: UNODC.

14. Chapon, J. (1992). 'Opium ravages Northern Vietnam province'. Agence France Presse, 24 April 1992.

15. Cima, R. (1986). Narcotics and the police and military of South and Southeast Asia. Washington: Library of Congress.

16. Cima, R. J. (1989). Vietnam's economic reform: approaching the 1990s. Asian Survey, 29(8), 786-799.

17. Commission on Narcotic Drugs. (1950). Summary of annual reports of governments relating to opium and other narcotic drugs. E/NR.1950/Summary.

18. Commission on Narcotic Drugs. (1952). Summary of annual reports of governments relating to opium and other narcotic drugs. E/NR.1952/Summary.

19. Commission on Narcotic Drugs. (1953). Summary of annual reports of governments relating to opium and other narcotic drugs. E/NR.1953/Summary.

20. Commission on Narcotic Drugs. (1954). Summary of annual reports of governments relating to opium and other narcotic drugs. E/NR.1954/Summary.

21. Commission on Narcotic Drugs. (2010). Drug control, crime prevention and criminal justice: a human rights perspective. 3 March 2010. E/CN.7/2010/CRP.6-/CN.15/2010/CRP.1 
Windle, J. (2012). 'The Suppression of Illicit Opium Production in Viet Nam: An Introductory Narrative'. Crime, Law and Social Change, 57(4), pp. 425-439. Pre-print copy.

22. Corlin, C. (2004). Hmong and the land question in Vietnam: national policy and local concepts of the environment. In N. Tapp, J. Michaud, C. Culas, \& G. Y. Lee (Eds.),

Hmong/Miao in Asia. Chiang Mai: Silkworm Books.

23. Culas, C. (2000). Migrants, runaways and opium growers: origins of the Hmong in Laos and Siam in the nineteenth and early twentieth century. In J. Michaud (Ed.), Turbulent times and enduring peoples: mountain minorities in the South-East Asian Massif. Surrey: Curzon Press.

24. Culas, C., \& Michaud, J. (2004). A contribution to the study of the Hmong (Miao)

migrants and history. In N. Tapp, J. Michaud, C. Culas, \& G. Y. Lee (Eds.), Hmong/Miao in Asia. Chiang Mai: Silkworm Books.

25. Drug Enforcement Agency. (1992). Worldwide heroin situation, 1991. Washington: US Department of Justice.

26. Dommen, A. (1971). Conflict in Laos: the politics of neutralization. London: Pall Mall Press.

27. Feingold, D. (1970). Opium and politics in Laos. In N. Adams \& A. McCoy (Eds.), Laos: war and revolution. New York: Harper Colophon Books.

28. Fforde, A. (2009). Economics, history, and the origins of Vietnam's post-war economic success. Asian Survey, 49(3), 484-504.

29. Finkelstein, D. M. (1987). Vietnam: a revolution in crisis. Asian Survey, 27(9), 973-990.

30. Freedom House. (2006). The worst of the worst 2005-Vietnam. Available at http://www.unhcr.org/refworld/docid/4917f82ec.html

31. Human Rights Watch. (1992). World report. Available at http://www.hrw.org/en/node/79288

32. Human Rights Watch. (2000). Human rights issues in Vietnam. HWR Briefing Paper.

Available at http://hrw.org/english/docs/2000/11/01/vietna3106.htm

33. Human Rights Watch. (2001). World report. Available at

http://www.hrw.org/en/node/79288

34. Human Rights Watch. (2003). World report. Available at http://www.hrw.org/en/node/79288

35. Human Rights Watch. (2005). Key human rights issues in Vietnam. HWR Briefing Paper. Available at http://hrw.org/english/docs/2005/06/17/vietna11151.htm

36. Independent. (2001). 'Eradication programme shrinks Vietnam's opium-producing poppy fields'. Independent, 21 February 2001. 
Windle, J. (2012). 'The Suppression of Illicit Opium Production in Viet Nam: An Introductory Narrative'. Crime, Law and Social Change, 57(4), pp. 425-439. Pre-print copy.

37. International Narcotics Control Board. (1974). Report for the international narcotics control board for 1974. E/INCB/24.

38. International Narcotics Control Board. (1993). Report for the international narcotics control board for 1993. E/INCB.

39. Joy, M. (1953). Correspondence. The national archives of the UK: FO 371/106801.

40. Kiem, N. H. (1994). 'Drug addiction in the northern mountain region: facts and solutions' Quan Doi Nhan Dan [Vietnamese] 11 April 1994. In BBC Summary of World Broadcasts, 5 May 1994.

41. League of Nations. (1938). Advisory committee on traffic in opium and other dangerous drugs: report to the council: concerning the preparatory work for the conference to consider the possibility of limiting and controlling the cultivation of the opium poppy and the production of raw opium and controlling other raw materials for the manufacture of opium alkaloids. Geneva: League of Nations.

42. McAlister, J. T. (1967). Mountain minorities and the Viet Minh: a key to the Indochina war. In P. Kunstadter (Ed.), Southeast Asian tribes, minorities, and nations: volume II. New Jersey: Princeton University Press.

43. McCoy, A. (2003). The politics of heroin: CIA complicity in the global drug trade.

Chicago: Lawrence Hill Books.

44. Michaud, J. (1997). From Southwest China into upper Indochina: an overview of Hmong (Miao) migrations. Asia Pacific Viewpoint, 38(2), 119-130.

45. Michaud, J., \& Turner, S. (2000). The Sa Pa marketplace, Lao Cai Province Vietnam. Asia Pacific Viewpoint, 41(1), 5-100.

46. Morlock, G. A. (1944). Limitation on the production of opium. Dep State Bull, 6(285), 723-727. The National Archives of the UK: FO 371/50647.

47. Murphy, M., \& Steele, R. (1971). The world heroin problem. Washington: US Government Printing Office.

48. National Narcotics Intelligence Consumers Committee. (1978-1993). The supply of drugs to the US illicit market. Washington: US Government Printing Office.

49. Nguyen, H. P. T. (2008). Legislative implementation by Vietnam of its obligations under the United Nations drug control conventions. $\mathrm{PhD}$ thesis for University of Wollongong, Australia. Available at http://ro.uow.edu.au/theses/30 50. Nguyen, V. T., \& Scannapieco, M. (2008). Drug abuse in Vietnam: a critical review of the literature and implications for future research. Addiction, 103(4), 535-543. 
Windle, J. (2012). 'The Suppression of Illicit Opium Production in Viet Nam: An Introductory Narrative'. Crime, Law and Social Change, 57(4), pp. 425-439. Pre-print copy.

51. Penal Code (2005). Available at

http://www.unodc.org/enl/showDocument.do?documentUid02484\&cuntry0VIE

52. Pike, D. (1982). Vietnam in 1981: biting the bullet. Asian Survey, 22(1), 69-77.

53. Poffenberger, M., Chung, V. T., Crystal, E., Dzung, N. H., Phon, N. H., Sikor, T.,

Sowerwine, J. and Walpole, P. (1998). Stewards of Vietnam's upland forests: a collaborative study by the forest inventory and planning institute and the Asia forest network. Available at http://www.communityforestryinternational.org/Publication/reserch_reports/Stewards_of_vie tnam_upland_forestry/index

54. Quang, V. D. (2004). The Hmong and forest management in Northern Vietnam's mountainous areas. In N. Tapp, J. Michaud, C. Culas, \& G. Y. Lee (Eds.), Hmong/Miao in Asia. Chiang Mai: Silkworm Books.

55. Rapin, A., Khue, D. H., Duc, D. N., Eyres, J., Tran, V. C., Higgs, P., \& Duan, N. V. (2003). Ethnic minorities, drug use and harm in the highlands of Northern Vietnam: a contextual analysis of the situation in six communes from Son La, Lai Chau, and Lao Cai. Bangkok: UNODC.

56. Rerkasem, K. (2002). 'Module 1: conceptual framework for alternative development projects'. In UNODC. (Ed.), A manual on monitoring and evaluation for alternative development projects. Available at http://www.unodc.org/pdf/Alternative\%20Development/Manual_MonitoringEvol.pdf 57. Robins, L. N., Helzer, J. E., Hesselbrock, M., \& Wish, E. (1998). Vietnam veterans three years after Vietnam: how our study changed our view of heroin. In J. A. Schaler (Ed.), Drugs: should we legalize, decriminalise or deregulate? New York: Promethers Books. 58. Smith, M. J., Clarke, R. V., \& Pease, K. (2002). Anticipatory benefit in crime prevention. In N. Tilley (Ed.), Analysis for crime prevention. Monsey: Criminal Justice Press.

59. Stuart-Fox, M. (1997). A history of Laos. Cambridge: Cambridge University Press.

60. The Law on Preventing and Combating Narcotic Drugs (2000). Available at http://www.unodc.org/enl/showDocument.do?documentUid02304\&cuntry0VIE 61. Thomson, R. (1988). 'Chinese admit to seriousness of new opium war'. The Financial Post (Canada), 26 July 1988.

62. Torode, G. (1997). 'Opium growers to reap penalties'. South China Morning Post (Hong Kong), 7 May 1997.

63. Tuan, H. D. (2001). 'Vietnam: results of drug control programme in 1998-2000 and future directions in 2001-2005'. Alternative development: sharing good practices facing 
Windle, J. (2012). 'The Suppression of Illicit Opium Production in Viet Nam: An Introductory Narrative'. Crime, Law and Social Change, 57(4), pp. 425-439. Pre-print copy.

common problems. Regional Seminar on Alternative Development for Illicit Crop Eradication Policies, Strategies and Actions. 16- 19 July 2001. Myanmar: UNDCP.

64. UN. (1966). Report of the economic and social council on the work of the board in 1966. Geneva: United Nations. E/OB/22.

65. UN. (2010). UN treaty collection. Available at http://treaties.un.org

66. UN Drug Control Programme. (2001). United Nations drug control program in Vietnam. Available at http://www.unodc.org/eastasiaandpacific/index.html

67. UN General Assembly. (2010). The situation of human rights in the Islamic Republic of Iran. UN General Assembly: A/65/370

68. UN General Assembly. (2010). Report of the special rapporteur on the right of everyone to the enjoyment of the highest attainable standard of physical and mental health. UN General Assembly: A/65/255.

69. UN Office of Drug Control and Crime Prevention. (1997-2000). World drug report. Oxford: Oxford University Press.

70. UN Office of Drugs and Crime. (2005). Vietnam country profile. Hanoi: UNODC. 71. UN Office of Drugs and Crime. (2007). Alternative development in the Ky Son district. Available at http://www.unodc.org/eastasiaandpacific/index.html 72. UN Office of Drugs and Crime. (2002-2010). World drug report. Vienna: UNODC. State Department.

73. US State Department. (1999). Country reports on human rights practices. Available at http://www.state.gov/g/drl/rls/hrrpt/1999/78868.htm

74. US State Department. (2003). Country reports on human rights practices. Available at http://www.state.gov/g/drl/rls/hrrpt/2003/78868.htm

75. US State Department. (1996-2008). International narcotics control strategy report. Washington: US State Department.

76. Yamada, N. and Dung, N. T. (2005). 'Ky Son: a decade of sustainable alternative development'. Eastern Horizons. Autumn, 14-15.

77. Yu, Y. (1983). 'Peking denounces Vietnamese opium production and supply'. BBC Summary of World Broadcasts, 25 March 1983.

78. Viet Nam Economic Times. (1999). 'Fight to the death'. Vietnam Economic Times, 1 January 1999.

79. Viet Nam News Agency. (2007). 'Viet Nam reviews drugs fight'. VNA, 26 June 2007. 
Windle, J. (2012). 'The Suppression of Illicit Opium Production in Viet Nam: An Introductory Narrative'. Crime, Law and Social Change, 57(4), pp. 425-439. Pre-print copy.

80. Vogel, P. and Boonwaat, L. (2001). 'Ky Son alternative development project in Vietnam'. Alternative development: sharing good practices facing common problems. Regional Seminar on Alternative Development for Illicit Crop Eradication Policies, Strategies and Actions. 1619 July 2001. Myanmar: UNDCP.

81. Voice of Vietnam. (1994). 'Ministry steps up campaign against poppy growing in North'. BBC summary of world broadcasts, 2 February 1994.

82. Wekkin, G. (1982). The rewards of revolution: Pathet Lao policy towards the hill tribes since 1975. In M. Stuart-Fox (Ed.), Contemporary Laos: studies in the politics and society of the Lao people's democratic republic. London: University of Queensland Press.

83. Westermeyer, J. (1982). Poppies, pipes and people: opium and its use in Laos. Oxford: Oxford University Press.

84. Windle, J. (2010). 'International human rights law, the prescription to the failings of international narcotics control laws?'. Leicester: 2010 British Society of Criminology Conference. 